\title{
Exposure of human islets to cytokines can result in disproportionately elevated proinsulin release
}

\author{
Katleen Hostens, Dejan Pavlovic, Yasmeeni Zambre, Zhidong Ling, \\ Christiaan Van Schravendijk, Décio L. Eizirik, and Daniel G. Pipeleers
}

Diabetes Research Center, Vrije Universiteit Brussel, B-1090 Brussels, Belgium

Address correspondence to: Daniel G. Pipeleers, Diabetes Research Center, Vrije Universiteit Brussel, Laarbeeklaan 103, B-1090 Brussels, Belgium. Phone: 32-2-477-45-41; Fax: 32-2-477-45-45; E-mail: dpip@mebo.vub.ac.be.

Received for publication February 2, 1999, and accepted in revised form May 14, 1999.

\begin{abstract}
Infiltration of immunocytes into pancreatic islets precedes loss of $\beta$ cells in type 1 diabetes. It is conceivable that local release of cytokines affects the function of $\beta$ cells before their apoptosis. This study examines whether the elevated proinsulin levels that have been described in prediabetes can result from exposure of $\beta$ cells to cytokines. Human $\beta$-cell preparations were cultured for 48 or 72 hours with or without IL-1 $\beta$, TNF- $\alpha$, or IFN- $\gamma$, alone or in combination. None of these conditions were cytotoxic, nor did they reduce insulin biosynthetic activity. Single cytokines did not alter medium or cellular content in insulin or proinsulin. Cytokine combinations, in particular IL- $1 \beta$ plus IFN- $\gamma$, disproportionately elevated medium proinsulin levels. This effect expresses an altered functional state of the $\beta$ cells characterized by preserved proinsulin synthesis, a slower hormone conversion, and an increased ratio of cellular proinsulin over insulin content. The delay in proinsulin conversion can be attributed to lower expression of PC1 and PC2 convertases. It is concluded that disproportionately elevated proinsulin levels in pre-type 1 diabetic patients might result from exposure of their $\beta$ cells to cytokines released from infiltrating immunocytes. This hormonal alteration expresses an altered functional state of the $\beta$ cells that can occur independently of $\beta$-cell death.
\end{abstract}

J. Clin. Invest. 104:67-72 (1999).

\section{Introduction}

Infiltration of macrophages and $\mathrm{T}$ lymphocytes in the pancreatic islets precedes the destruction of insulinproducing $\beta$ cells in human diabetes (1). Indirect evidence suggests that the release of cytokines by infiltrating cells might be responsible for the loss of $\beta$ cells $(2,3)$. Cytokines are produced in islets of rodents that develop an autoimmune form of diabetes (4-6). They are also expressed in islets of patients with type 1 diabetes (7-9); higher circulating IL-1 $\alpha$ and TNF- $\alpha$ levels were measured in identical twins who developed type 1 diabetes than in those who did not (10). Addition of cytokine combinations to isolated rodent islets can lead to destruction of $\beta$ cells within 24 hours $(2,3)$; in human islet cell preparations, the cytotoxic effect was noticed only after more than 3 days of exposure (11). In the present study, we examined whether cytokineexposed human $\beta$ cells exhibit signs of functional impairment during the first 3 days of culture - before the appearance of apoptotic cells. The total amount of insulin released in the medium was taken as an index of the $\beta$ cells' secretory activity over this period. We compared the release of insulin with that of proinsulin, because the prediabetic stage of type 1 diabetes is often associated with disproportionately elevated proinsulin levels (12). Proinsulin is also elevated in first-degree relatives of type 1 diabetic patients positive for islet cell antibodies (13), as well as in normoglycemic siblings (14) and discordant twins (15) of type 1 diabetic patients. The present in vitro experiments thus test the possibility that disproportionately high proinsulin levels might serve as an early marker of a process that can ultimately result in apoptosis of human $\beta$ cells.

\section{Methods}

Isolation and culture of human islets. Human pancreata were obtained from organ donors (14 donors, $42 \pm 3$ years of age, range 18-59 years of age) at European hospitals affiliated with $\beta$ Cell Transplant (Brussels, Belgium), a European concerted action for islet cell transplantation in diabetes (16). Islets were isolated at the central unit of $\beta$ Cell Transplant and cultured for 24 hours in Ham's F10 medium supplemented with 1\% (wt/vol) BSA (Fraction V, RIA grade; Sigma Chemical Co., St. Louis, Missouri, USA), $0.075 \mathrm{mg} / \mathrm{mL}$ penicillin, $0.1 \mathrm{mg} / \mathrm{mL}$ streptomycin, $6.1 \mathrm{mmol} / \mathrm{L}$ glucose, $2 \mathrm{mmol} / \mathrm{L}$ glutamine, $2 \mathrm{mmol} / \mathrm{L}$ leucine, $2 \mathrm{mmol} / \mathrm{L}$ nicotinamide, and $2 \%$ human serum (16). On day 2 , the medium was replaced by serum-free Ham's F10 medium containing $1 \%$ BSA, $2 \mathrm{mmol} / \mathrm{L}$ glutamine, and 6.1 $\mathrm{mmol} / \mathrm{L}$ glucose (17). Culture was continued for 48 or 72 hours, in the absence or presence of cytokines, with the following, alone or in combination (18): human IL$1 \beta, 50 \mathrm{U} / \mathrm{mL}, 95 \%$ pure, $200 \mathrm{U} / \mathrm{ng}$ (Genzyme Pharmaceuticals, Cambridge, Massachusetts, USA); murine TNF- $\alpha, 1,000 \mathrm{U} / \mathrm{mL}$, 98\% pure, $220 \mathrm{U} / \mathrm{ng}$ (Innogenetics, Ghent, Belgium); human IFN- $\gamma, 1,000 \mathrm{U} / \mathrm{mL}, 97 \%$ pure, $47.5 \mathrm{U} / \mathrm{ng}$ (Genzyme Pharmaceuticals). In one set 
of experiments, L-nitro-methylarginine (L-MA; SigmaAldrich, Milwaukee, Wisconsin, USA) was added to the culture medium in order to suppress nitric oxide production (19). After culture, the medium was collected for insulin and proinsulin measurement and nitrite determination (20), and islet cells were collected for DNA (17) and insulin and proinsulin measurement. In one set of experiments, the islet cells were examined for their rates of proinsulin synthesis and conversion, as well as for PC1 and PC2 expression.

Measurement of protein and insulin and proinsulin synthesis. At the end of culture, islet cells were washed twice with labeling medium (Ham's F10 containing 1\% BSA, $2 \mathrm{mmol} / \mathrm{L}$ glutamine, and $10 \mathrm{mmol} / \mathrm{L}$ glucose) and pulse labeled for 30 minutes in this medium supplemented with $16.7 \mathrm{Ci} / \mathrm{mmol}^{3} \mathrm{H}$-tyrosine (specific activity $50 \mathrm{Ci} / \mathrm{mmol}$; Amersham International, Buckinghamshire, United Kingdom). After washing, cells were resuspended in $1 \mathrm{~mL}$ chase medium (Ham's F10 containing 1\% BSA, $2 \mathrm{mmol} / \mathrm{L}$ glutamine, $2 \mathrm{mmol} / \mathrm{L} \mathrm{CaCl}_{2}$, $2.5 \mathrm{mmol} / \mathrm{L}$ glucose, and $1 \mathrm{mmol} / \mathrm{L}$ tyrosine), gassed with $5 \% \mathrm{CO}_{2}$ and $95 \% \mathrm{O}_{2}$, and then incubated at $37^{\circ} \mathrm{C}$ for 60 or 120 minutes. After resuspension in chase medium, cells were centrifuged at $1,000 \mathrm{~g}$ for 5 minutes. Supernatants were collected and stored at $-20^{\circ} \mathrm{C}$. Pellets were extracted in $1 \mathrm{~mL} 2 \mathrm{M}$ acetic acid BSA for measurement of total protein and proinsulin biosynthesis (17) and were analyzed for proinsulin conversion rates using HPLC and Biogel P-10 columns (Bio-Rad Laboratories Inc., Richmond, California, USA), as described previously $(21,22)$. Elution fractions were counted, and counts corresponding to the insulin peak were expressed as a percentage of total counts. The half-time of proinsulin disappearance $\left(t_{1 / 2}\right)$ was calculated as the time required for $50 \%$ of the newly formed proinsulin to shift to insulin.

Hormone assays. The insulin RIA was carried out as previously described (23). The proinsulin RIA is based on the 2-step nonequilibrium assay developed by Bowsher et al. (24). Human insulin and C peptide do not crossreact with proinsulin in this assay (24). Polyclonal goat anti-human proinsulin $(100 \mu \mathrm{L}$; Linco Research Inc., St. Charles, Missouri, USA) was added to a $200-\mu$ L sample or proinsulin standard (kindly donated by F. SodoyezGoffaux, Centre Hospitalier Universitaire, Liège, Belgium). When undiluted perifusion samples were analyzed, perifusion medium was used for background determination; background values were not different from those with buffer alone. After an 18-hour incubation at $20^{\circ} \mathrm{C}, 100 \mu \mathrm{L}$ of radiolabeled proinsulin (also provided by F. Sodoyez-Goffaux) was added, and the incubation was continued for 24 hours. Bound and free proinsulin were separated by adding $1 \mathrm{~mL}$ horse antisheep-coated Sepharose (Pharmacia Decanting Suspension $\mathrm{n}^{\circ} 2$; Pharmacia Biotech $A B$, Uppsala, Sweden), incubating for 20 minutes at $20^{\circ} \mathrm{C}$, and centrifuging at $2,500 \mathrm{~g}$. Pellets were washed with $1 \mathrm{~mL}$ PBS containing $0.25 \%$ BSA and then were counted. Standard curves were calculated by on-line RIA Calc software (Pharma- cia, Wallac, Finland), and values were accepted if they showed 2 linear dilutions. The sensitivity of the assay was 5 pM (blanc-3 SD), and the interassay coefficient of variation was $11 \%, 6 \%$, and $5 \%$ for 20,60 , and 100 pg proinsulin per tube $(n=12)$, respectively. The intra-assay coefficient of variation was $3 \%, 4 \%$, and $8 \%$ for 70,35 , and $10 \mathrm{pg}$ proinsulin per tube $(n=6)$, respectively.

Immunoblot analysis. The expression of PC1 and PC2 was analyzed by Western blot as described previously (25). Briefly, human islets were sonicated in $50 \mu \mathrm{L}$ SDSgel sample buffer (25); run on $10 \%$ SDS-polyacrylamide gels; electrically transferred to nitrocellulose filters; and incubated with rabbit anti-rat PC1 antibody $(1: 1,000$; kindly provided by I. Linberg, Louisiana State University School of Medicine, New Orleans, Louisiana, USA), rabbit anti-rat PC2 (1:1,000; kindly provided by C.J., Rhodes, University of Texas-Southwestern Medical Center, Dallas, Texas, USA), or goat anti- $\beta$-actin (1:1,000; Santa Cruz Biotechnology Inc., Santa Cruz, California, USA). Horseradish peroxidase-linked immunoglobulins were used as second antibodies, and peroxidase activity was detected by enhanced chemiluminescence (ECL; Amersham International). The intensity of the bands was quantified on an Ultroscan XL Enhanced Laser Densitometer (LKB; Pharmacia Biotech $\mathrm{AB}$ ), and expressed in arbitrary units of OD.

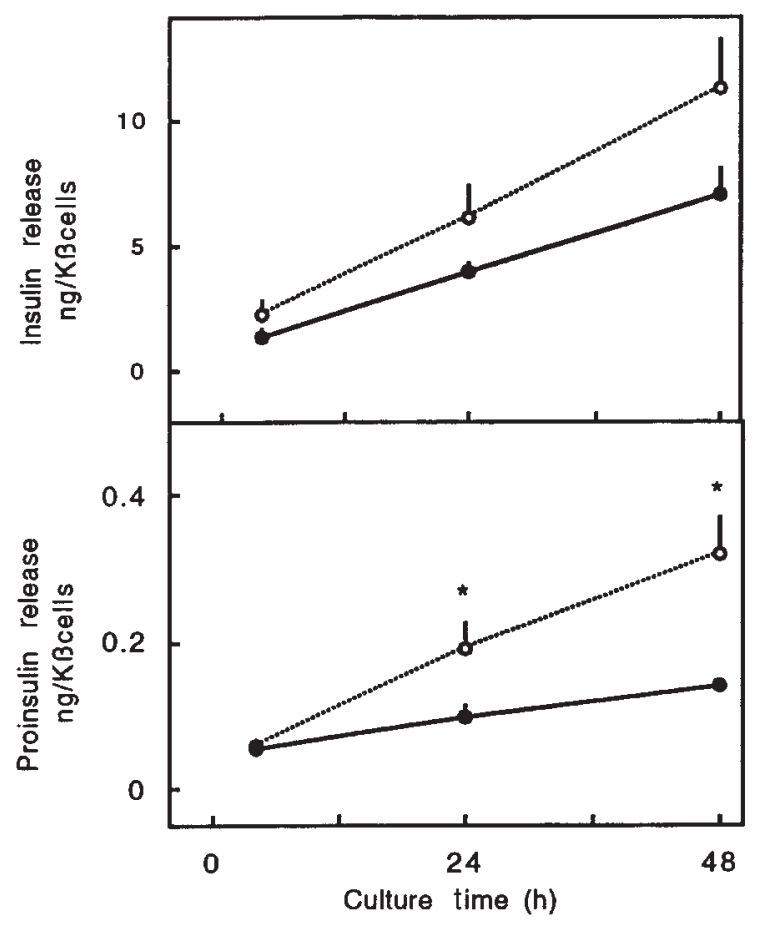

Figure 1

Time course of cytokine-induced increase in proinsulin release. Cells were cultured in the presence (open circles) or absence (filled circles) of IL-1 $\beta(50 \mathrm{U} / \mathrm{mL})$ plus IFN- $\gamma(1,000 \mathrm{U} / \mathrm{mL})$. Medium was sampled at 4, 24, and 48 hours and assayed for insulin and proinsulin. Data represent mean \pm SEM of 3 independent experiments. Proinsulin release between 4 and 24 or 48 hours is significantly higher during cytokine exposure. Statistical significance of difference in controls was calculated by Mann-Whitney $U$ test. ${ }^{*} P<0.05$. 
Table 1

Effect of cytokines on cellular and medium content of insulin and proinsulin and on medium content of nitrite

\begin{tabular}{|c|c|c|c|c|c|c|c|c|c|c|}
\hline \multirow[b]{3}{*}{$\begin{array}{l}\text { Culture } \\
\text { condition }\end{array}$} & \multicolumn{3}{|c|}{ Proinsulin } & \multicolumn{3}{|c|}{ Insulinz } & \multicolumn{3}{|c|}{ Proinsulin/Insulin ${ }^{A}$} & \multirow[t]{2}{*}{ Nitrite } \\
\hline & Medium & Cells & Total & Medium & Cells & Total & Medium & Cells & Total & \\
\hline & & $\mathrm{pmol} / \mathrm{K} \beta$ cells & & & $\mathrm{pmol} / \mathrm{K} \beta$ cells & & & $10-2$ & & $\begin{array}{l}\mathrm{pM} / \mu \mathrm{g} \\
\text { DNA.1h }\end{array}$ \\
\hline Control & $0.021 \pm 0.003$ & $0.020 \pm 0.004$ & $0.041 \pm 0.008$ & $1.05 \pm 0.27$ & $1.13 \pm 0.25$ & $2.18 \pm 0.50$ & $2.3 \pm 0.3$ & $1.8 \pm 0.2$ & $2 . z 0 \pm 0.2$ & $0.6 \pm 0.3$ \\
\hline IL-1及 & $0.023 \pm 0.003$ & $0.021 \pm 0.007$ & $0.043 \pm 0.010$ & $1.27 \pm 0.32$ & $0.68 \pm 0.13$ & $2.02 \pm 0.45$ & $2.2 \pm 0.4$ & $2.5 \pm 0.4$ & $2.2 \pm 0.2$ & $0.9 \pm 0.3$ \\
\hline TNF- $\alpha$ & $0.019 \pm 0.003$ & $0.020 \pm 0.007$ & $0.039 \pm 0.010$ & $0.93 \pm 0.28$ & $0.92 \pm 0.23$ & $1.85 \pm 0.53$ & $2.5 \pm 0.3$ & $2.0 \pm 0.2$ & $2.2 \pm 0.1$ & $0.6 \pm 0.3$ \\
\hline $\mathrm{IFN}-\gamma$ & $0.022 \pm 0.006$ & $0.019 \pm 0.007$ & $0.041 \pm 0.011$ & $1.22 \pm 0.42$ & $1.02 \pm 0.33$ & $2.23 \pm 0.75$ & $2.5 \pm 0.5$ & $1.9 \pm 0.4$ & $2.1 \pm 0.2$ & $0.9 \pm 0.3$ \\
\hline $\begin{array}{l}\text { IL-1 } \beta+ \\
\text { TNF- } \alpha\end{array}$ & $0.034 \pm 0.007^{\mathrm{B}}$ & $0.024 \pm 0.006$ & $0.059 \pm 0.012^{B}$ & $1.53 \pm 0.45$ & $0.78 \pm 0.15^{\mathrm{B}}$ & $2.30 \pm 0.60$ & $2.8 \pm 0.4$ & $3.2 \pm 0.7^{C}$ & $2.8 \pm 0.3$ & $1.1 \pm 0.5$ \\
\hline $\begin{array}{l}\text { IL- } 1 \beta+ \\
\text { IFN- } \gamma\end{array}$ & $0.043 \pm 0.009^{c}$ & $0.022 \pm 0.007$ & $0.066 \pm 0.014^{\mathrm{B}}$ & $1.35 \pm 0.33$ & $0.68 \pm 0.17 \mathrm{c}$ & $2.02 \pm 0.47$ & $3.8 \pm 0.7^{\mathrm{B}}$ & $3.1 \pm 0.7 c$ & $3.3 \pm 0.4^{B}$ & $10.7 \pm 3^{c}$ \\
\hline $\begin{array}{l}\text { TNF- } \alpha+ \\
\text { IFN- } \gamma\end{array}$ & $0.032 \pm 0.008$ & $0.026 \pm 0.008$ & $0.058 \pm 0.016$ & $1.27 \pm 0.48$ & $0.83 \pm 0.23^{C}$ & $2.10 \pm 0.65$ & $3.5 \pm 0.7$ & $2.8 \pm 0.5$ & $3.0 \pm 0.3^{B}$ & $0.9 \pm 0.5$ \\
\hline $\begin{array}{l}\text { IL- } 1 \beta+ \\
\text { TNF- } \alpha+\text { IF }\end{array}$ & $\begin{array}{l}0.067 \pm 0.022^{C} \\
=N-\gamma\end{array}$ & $0.026 \pm 0.007$ & $0.091 \pm 0.026^{B}$ & $1.42 \pm 0.40$ & $0.60 \pm 0.15^{c}$ & $2.22 \pm 0.47$ & $4.7 \pm 0.7 \mathrm{C}$ & $4.3 \pm 1.1^{c}$ & $4.2 \pm 0.6^{B}$ & $14.3 \pm 4.5^{c}$ \\
\hline
\end{tabular}

Human islets were cultured for 72 hours in the presence of $\mathrm{IL}-1 \beta(50 \mathrm{U} / \mathrm{mL})$, TNF- $\alpha(1,000 \mathrm{U} / \mathrm{mL})$, or IFN- $\gamma(1,000 \mathrm{U} / \mathrm{mL})$, alone or in combination. Data represent mean \pm SEM of 7 independent experiments. Statistical significance of differences with control was calculated by Wilcoxon rank sum test. ${ }^{A}$ Ratio of molar concentrations. ${ }^{\mathrm{B}} P<0.05$. ${ }^{\mathrm{C}} P<0.02$.

Competitive RT-PCR analysis. The mRNA of cultured human islets was isolated using oligo $(\mathrm{dT})_{25}$-coated polystyrene beads (Dynabeads; Dynal, Oslo, Norway), and cDNA was prepared with a GeneAmp RNA-PCR Kit (Perkin-Elmer Corp., Norwalk, Connecticut, USA) as previously described (25). PC1 and PC2 mRNA levels were quantified by competitive PCR (25). Competitor DNA for PC1 was synthesized from human islet cDNA using a 2-step PCR method (26) with a linker primer (5'TTGGTGTGCACTGAACAGTGAAGCTGCTTCTG-3') and target-specific primers (5'-TTGGTGTGCACTGAACAGTG-3' and 5'-GCCCATATCACACGATCATC$\left.3^{\prime}\right)$. Its PCR products are shorter than the target cDNA. The competitor DNA for PC2 was prepared from rat cDNA using the primers corresponding to an identical sequence in rat and human PC2 cDNAs (5'-AGAGATTCCACTGTGTGGGA-3' and 5'-CAAAATGGACTTGGTGCCCA-3'). Human and rat PC2 fragments can be discriminated following digestion with $R s a \mathrm{I}$, which is expected to cleave only the rat PC2 sequence. The competitor DNAs were purified using a QIAquick spin PCR purification kit (QIAGEN GmbH, Hilden, Germany) and were quantified in a spectrophotometer (UV-160A; Shimadzu Europa GmbH, Kyoto, Japan). PCR reactions were carried out in a volume of 25 $\mu \mathrm{L}$ containing cDNA, competitor DNA, $10 \mathrm{mmol} / \mathrm{L}$ Tris$\mathrm{HCl}$ ( $\mathrm{pH} 8.3$ ), $1.5 \mathrm{mmol} / \mathrm{L} \mathrm{MgCl}_{2}, 0.04 \mathrm{mmol} / \mathrm{L}$ of each dNTP, $0.4 \mathrm{mmol} / \mathrm{L}$ of target-specific primers, and 0.625 U AmpliTaq DNA polymerase (Perkin-Elmer Corp.). PCR was performed in a PTC-200 DNA thermal cycler (MJ Research, Watertown Massachusetts, USA) using the following conditions: initial denaturation for 2.5 minutes at $94^{\circ} \mathrm{C}$, and 35 cycles of denaturation for 45 seconds at $94^{\circ} \mathrm{C}$, annealing for 45 seconds at $58^{\circ} \mathrm{C}$, and extension for 90 seconds at $72^{\circ} \mathrm{C}$. The last step was a 10 minute extension at $72^{\circ} \mathrm{C}$. A cDNA aliquot was used to amplify the "housekeeping" gene GAPDH in order to confirm equal cDNA loading. Ten microliters of PCR products was separated by electrophoresis in $2 \%$ (Agarose MS; Boehringer Mannheim, Brussels, Belgium) molecular screening agarose gel and stained with ethidium bromide. To discriminate the human and rat PC2 PCR fragments, $12 \mu \mathrm{L}$ of each PCR reaction was digested overnight at $37^{\circ} \mathrm{C}$ with $15 \mathrm{U}$ of RsaI (Eurogentec, Seraing, Belgium) before loading on the gel. The gels were photographed under ultraviolet transillumination using Kodak Digital Science DC40 camera (Eastman Kodak Co., Rochester, New York, USA). The PCR band intensities on the image were quantified by Biomax 1D Image Analysis Software (Eastman Kodak Co.) and expressed in pixel intensities. The ratios of target cDNA to competitor DNA PCR products were plotted against the amount of competitor DNA added to the reaction.

Data analysis. Data analysis was performed with Statview SE and Graphics for Macintosh. Results are expressed as mean \pm SEM. Statistical significance of differences was calculated by Wilcoxon rank sum test and Mann-Whitney $U$ test.

\section{Results}

Effects of cytokines on cellular content and release of insulin and proinsulin. Culture of human islets for 72 hours in the presence of IL- $1 \beta$, TNF- $\alpha$, or IFN- $\gamma$ did not alter the cellular or medium content in insulin or proinsulin (Table 1). Combinations of these cytokines decreased cellular insulin content but did not affect total insulin recovery, i.e., cells plus medium (Table 1), suggesting a stimulatory effect on release. The higher insulin content in the medium only reached statistical significance for the combinations with IL-1 and when expressed as a percentage of total insulin: release of $61-65 \%$ of total in IL$1 \beta$ plus IFN- $\gamma$ and/or TNF- $\alpha$ versus $47 \%$ in the control $(P<0.02$ for IL-1 $\beta+$ IFN- $\gamma ; P<0.05$ for IL-1 $\beta+$ TNF- $\alpha)$. These IL-1 combinations increased the medium proin- 
sulin content in absolute terms, without reducing the cellular proinsulin content; consequently, total proinsulin recovery (i.e., cells plus medium) was higher than in the control $(P<0.05)$. As a result of these preferential effects on medium and total proinsulin content, the medium and cellular ratio of proinsulin over insulin was increased in these IL-1 combinations (Table 1). Because these cytokine-induced alterations were most marked in the combinations with IL- $1 \beta$ plus IFN- $\gamma$, we selected this condition for subsequent experiments.

The stimulatory effect on hormone release was not yet noticed after a 4-hour exposure to IL- $1 \beta$ plus IFN- $\gamma$ (Figure 1). The medium proinsulin and insulin content after a 4-hour culture period was relatively high, which is, at least in part, attributable to hormone discharge during resuspension of the cells in culture medium and subsequent plating in the dishes. Hormone release in the following 20- or 44-hour culture periods was higher in the cytokine condition, reaching statistical significance for proinsulin (Figure 1). The cytokine-induced increase in proinsulin release occurs independently of nitric oxide formation: addition of L-MA prevented nitrite accumulation but did not prevent the 2 -fold increase in medium proinsulin (Table 2). The nitric oxide independence of the observed cytokine effect is also apparent from the data obtained with the IL-1 $\beta$ plus TNF- $\alpha$ combination: although nitrite accumula-
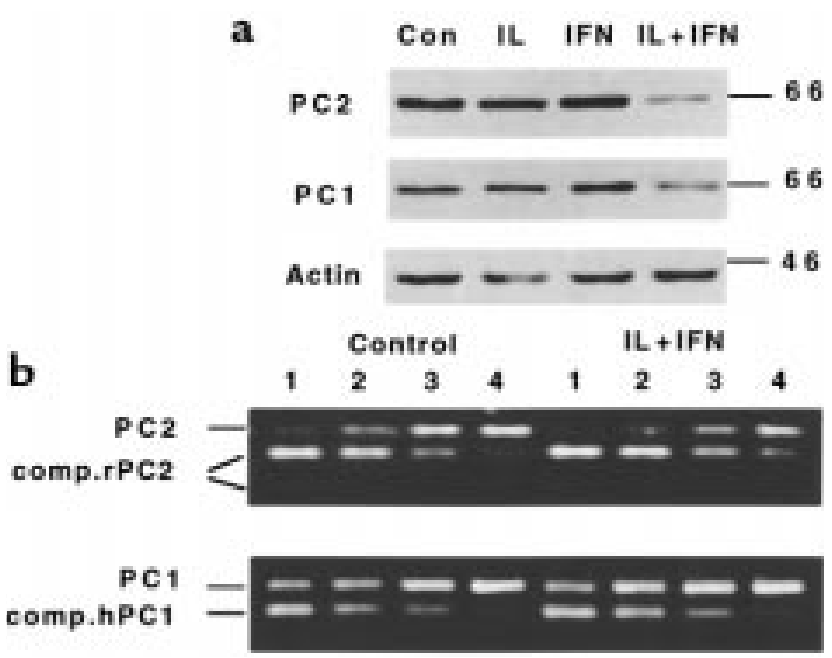

\section{Figure 2}

(a) Western blot analysis of PC1 and PC2 protein expression in human islets cultured for 48 hours in the presence or absence of IL$1 \beta(50 \mathrm{U} / \mathrm{mL})$, IFN- $\gamma(1,000 \mathrm{U} / \mathrm{mL})$, or IL- $1 \beta$ plus IFN- $\gamma$. (b) Competitive PCR analysis of PC1 and PC2 mRNA expression in control and cytokine-cultured (IL-1 $\beta+$ IFN- $\gamma, 48$ hours) human islets. Lanes 1-4 contain the same amount of cDNA from the same human islet preparation and a decreasing amount of competitor $\operatorname{DNA}(0.5,0.125,0.03$, and 0.0075 amol, respectively). Competitor DNA for PC2 was prepared from rat CDNA for PC1 from human CDNA. After amplification, $\mathrm{PC} 1$ products were directly run on $2 \%$ agarose-ethidium bromide gel, whereas PC2 products were digested with Rsal before separation. Competitor rat PC2 appears as 2 bands ( 151 and 65 bp) after Rsal restriction, but human PC2 remains intact. The figures are representative of 3 independent experiments. tion was not increased, proinsulin release was elevated and cellular insulin content decreased (Table 1).

Effect of cytokines on proinsulin conversion. Culture for 48 hours in the presence of IL- $1 \beta$ plus IFN- $\gamma$ did not alter the rate of proinsulin synthesis during a subsequent 30 minute pulse at $10 \mathrm{mmol} / \mathrm{L}$ glucose $(0.64 \pm 0.07 \mathrm{dpm} / \beta$ cell vs. control $0.80 \pm 0.09 \mathrm{dpm} / \beta$ cell in control preparations; $n=3$ ). When these pulse-labeled cell preparations were chased for 60 and 120 minutes, a delay was noticed in the rate of disappearance of newly formed proinsulin: $t_{1 / 2}$ of $52 \pm 7$ minutes in the IL- $1 \beta$ plus IFN$\gamma$ condition vs. $38 \pm 1$ minutes in control (calculated from Table $3 ; P<0.05$ ). At the end of these chase periods, cytokine-treated cells retained larger fractions of the unconverted proinsulin and the des $(31,32)$ intermediate, which is suggestive of a delay in the 2 conversion reactions (Table 3 ). The cytokine-treated cells' ratio of newly synthesized proinsulin over insulin was 3- to 6fold higher than in control cells (Table 3).

Effect of cytokines on the expression of conversion enzymes. Culture for 48 hours in the presence of IL- $1 \beta$ plus IFN$\gamma(\mathrm{CK})$ reduced PC1 and PC2 expression by $40-45 \%$ (Figure 2a): OD values for PC1 were $0.30 \pm 0.03$ (control) and $0.18 \pm 0.02(\mathrm{CK} ; n=5, P<0.05)$. For PC2, they were $0.90 \pm 0.09$ (control); $0.50 \pm 0.20(\mathrm{CK} ; n=8$, $P<0.001)$. This reduction was already observed after a 24-hour exposure to the cytokines (data not shown); it did not occur after addition of the single cytokines (Figure 2). When the blots were exposed for a longer time, both control and cytokine condition contained an additional $87-\mathrm{kDa}$ band with the PC1 antibody and a $75-\mathrm{kDa}$ band with the PC2 antibody, but these bands represented less than $10 \%$ of the intensities of 65 - to 66$\mathrm{kDa}$ bands (data not shown). Using a competitive PCR analysis, cellular PC2 mRNA content was not significantly decreased ( $27 \pm 9 \%$ decrease; $P>0.05, n=3)$ after a 48-hour exposure to the cytokine combination, whereas PC1 mRNA remained at the same level as in the control condition ( $95 \pm 8 \%$ of control; $n=3$ ) (Figure $2 \mathrm{~b})$. The cytokines did not modify GAPDH mRNA expression (data not shown).

\section{Discussion}

This in vitro study indicates that 1-3 days' exposure of human islets to a combination of IL- $1 \beta$ plus IFN- $\gamma$ results in elevated extracellular proinsulin levels. The release of proinsulin was disproportionate to that of insulin, as indicated by the higher ratio of proinsulin over insulin in the medium. These features are also characteristic of the prediabetic stage of type 1 diabetes (12-15).

Our experiments identify cellular processes that might be involved in this cytokine effect. After a 72hour exposure to IL- $1 \beta$ plus IFN- $\gamma$, human islets present the same proinsulin content as in the control condition, but their insulin content is $40 \%$ lower. This reduction in cellular insulin is not a consequence of a cytodestructive process, because the number of necrotic or apoptotic cells was not increased in the cytokine 
Table 2

Effect of L-MA on cytokine-induced increase in proinsulin release

\begin{tabular}{lccc}
\hline Culture condition & & Proinsulin & Nitrite \\
& L-MA & $\mathrm{ng} / \mathrm{K} \beta$ cells & $\mathrm{pM} / \mu \mathrm{g}$ DNA.1h \\
Control & - & $0.23 \pm 0.07$ & $1.0 \pm 0.6$ \\
& + & $0.17 \pm 0.04$ & $0.7 \pm 0.4$ \\
$\mathrm{IL}-1 \beta+\mathrm{IFN}-\gamma$ & - & & \\
& + & $0.43 \pm 0.09^{\mathrm{A}}$ & $17.1 \pm 1.7^{\mathrm{A}}$ \\
& & $0.34 \pm 0.07^{\mathrm{A}}$ & $1.8 \pm 2.1$
\end{tabular}

Human islets were cultured for 48 hours with or without L-MA $(1 \mathrm{mmol} / \mathrm{L})$ in the presence or absence of IL-1 $\beta+$ IFN- $\gamma$. Data represent mean \pm SEM of 5 independent experiments. Statistical significance of differences with respective control was calculated by Wilcoxon rank sum test. ${ }^{A} P<0.05$.

condition and because the proinsulin biosynthetic activity of those preparations was not affected. The lower cellular insulin content appears to be the result of 2 processes. First, the $\beta$ cells exhibited a higher secretory activity during the preceding 3 -day culture with cytokines. Second, the cells convert proinsulin into insulin at a 1.4-fold lower rate than control cells. This delay is caused by a slower conversion of proinsulin into the des $(31,32)$ intermediate and the conversion of this intermediate into insulin. The delayin proinsulin conversion might be attributable to a lower expression of the PC1 and PC2 convertases; this lower protein expression was not associated with lower mRNA levels, suggesting that it is caused posttranscriptionally. The suppressive effect of cytokines on convertase expression by human $\beta$ cells is not necessarily specific for these proteins; it may reflect - as in rat $\beta$ cells (25) - an alteration in $\beta$-cell phenotype in which several other proteins are downregulated and others are upregulated.

Human $\beta$ cells can thus be exposed for 3 days to IL- $1 \beta$ plus IFN- $\gamma$ without an impairment of their hormone synthetic activity. The total of released insulin plus cellular insulin at the end of the 3-day exposure was indeed not lower than that in control cells, and their rates of proinsulin synthesis after 3 days were not different from those in control preparations. However, human $\beta$ cells exhibited an altered functional state that was characterized by an increased hormone release with disproportionately elevated proinsulin levels as compared with insulin. At the end of this 3-day exposure to the cytokines, their cellular insulin store was reduced, but not their proinsulin content, which resulted in an elevated cellular ratio of proinsulin over insulin. Exposure of human islets to IL- $1 \beta$ plus IFN- $\gamma$ can thus also cause an increased ratio of proinsulin over insulin content in the $\beta$ cells, which should be reflected in the extracellular medium during subsequent measurements.

Disproportionately elevated serum proinsulin levels have been noticed in the prediabetic stage of type 1 dia-

Table 3 ney $U$ test. ${ }^{A} P=0.05 .{ }^{B} P<0.05$. betes (12-15). The underlying causes have not yet been identified. The present observations indicate that prolonged exposure to more than one cytokine, in particular IL- $1 \beta$ plus IFN- $\gamma$, might represent one of the reasons. This condition could occur in islets with infiltrating immune cells. It is not necessarily associated with $\beta$-cell death, although apoptosis of $\beta$ cells might ultimately result from longer exposure to cytokines (11). The presence of disproportionately elevated proinsulin levels in the serum might thus represent a peripheral marker for $\beta$ cells exposed to cytokines and, hence, to immune cells. Presently, we have no direct evidence to support the validity of this extrapolation to the in vivo condition. Further studies are therefore needed to evaluate the clinical relevance of the present findings versus other potential mechanisms for the elevated proinsulin levels in prediabetic subjects (27-31).

\section{Acknowledgments}

We thank the staff of the central unit of $\beta$ Cell Transplant for preparing the human islet cells, and Lutgart Heylen, Gabriel Schoonjans, and Caroline Jordens for technical assistance in the present work. We are grateful to F. Sodoyez-Goffaux and P. Houssa (University of Liège, Liège, Belgium) and R. Bowsher (Lilly Laboratory for Clinical Research, Wishard Memorial Hospital, Indianapolis, Indiana, USA) for their help in setting up the proinsulin assay; C. Rhodes for providing PC2 antibodies; I. Lindberg for providing PC1 antibodies; and B. Van Den Bogaert (Solvay, Statistics and Advanced Control Development, Brussels, Belgium) for analyzing the HPLC profiles. This work has been supported by grants from the Juvenile Diabetes Foundation International (JDF-995004), the Belgian Fonds voor Wetenschappelijk Onderzoek (FWOG-0376.97), and the serv-

Effect of cytokines on proinsulin conversion in human islets

\begin{tabular}{|c|c|c|c|c|}
\hline \multirow[b]{2}{*}{ Pretreatment } & \multirow{2}{*}{$\begin{array}{l}\text { Unconverted } \\
{ }^{3} \mathrm{H} \text {-proinsulin }\end{array}$} & \multicolumn{2}{|c|}{ Conversion to } & \multirow{2}{*}{$\begin{array}{c}\text { Ratio } \\
{ }^{3} \mathrm{H}-\mathrm{Pl} /{ }^{3} \mathrm{H}-\end{array}$} \\
\hline & & ${ }^{3} \mathrm{H}-\operatorname{des}(31,32)$ & ${ }^{3} \mathrm{H}$-insulin & \\
\hline \multicolumn{5}{|c|}{ Culture 48 hours } \\
\hline & \multicolumn{3}{|c|}{ Total ${ }^{3} \mathrm{H}$-proinsulin synthesis(\%) } & $10^{-2}$ \\
\hline \multicolumn{5}{|c|}{ 60-minute chase } \\
\hline Control & $20 \pm 2$ & $16 \pm 2$ & $64 \pm 4$ & $31 \pm 6$ \\
\hline $\mathrm{IL}-1 \beta+\mathrm{IFN}-\gamma$ & $40 \pm 7^{A}$ & $16 \pm 2$ & $44 \pm 6^{A}$ & $97 \pm 32^{B}$ \\
\hline \multicolumn{5}{|c|}{ 120-minute chase } \\
\hline Control & $2 \pm 0.2$ & $3 \pm 1$ & $95 \pm 1$ & $2 \pm 0.2$ \\
\hline $\mathrm{IL}-1 \beta+\mathrm{IFN}-\gamma$ & $10 \pm 2^{\mathrm{A}}$ & $8 \pm 2^{A}$ & $82 \pm 4^{\mathrm{A}}$ & $13 \pm 4^{\mathrm{B}}$ \\
\hline
\end{tabular}

Human islets were cultured for 48 hours with or without IL-1 $\beta+$ IFN- $\gamma$ before 30 -minute pulse incubation with ${ }^{3} \mathrm{H}$-tyrosine. Conversion of newly synthesized proinsulin was determined after a 60 - and 120-minute chase incubation. Cellular extracts were analyzed for the percentage of unconverted ${ }^{3} \mathrm{H}$-proinsulin, ${ }^{3} \mathrm{H}-\operatorname{des}(31,32)$, and ${ }^{3} \mathrm{H}$-insulin. Data represent mean $\pm \mathrm{SEM}$ of 3 independent experiments. Statistical significance of differences with respective controls was calculated by Mann-Whit- 
ices of the Prime Minister (Interuniversity Attraction Pole P4/21). Katleen Hostens is a Research Assistant of the Belgian Fonds voor Wetenschappelijk Onderzoek.

1. Bottazzo, G.F., et al. 1985. In situ characterization of autoimmune phenomena and expression of HLA molecules in the pancreas in diabetic insulitis. N. Engl. J. Med. 313:353-360.

2. Rabinovitch, A. 1993. Roles of cytokines in IDDM pathogenesis and islet $\beta$-cell destruction. Diabetes Reviews. 1:215-240.

3. Mandrup-Poulsen, T. 1996. The role of interleukin-1 in the pathogenesis of IDDM. Diabetologia. 39:1005-1029.

4. Rabinovitch, A., Suarez-Pinzon, W., El Seikh, A., Sorensen, O., and Power, R.F. 1996. Cytokine gene expression in pancreatic islet-infiltration leukocytes of BB rats: expression of Th1 cytokines correlates with $\beta$-cell destructive insulitis and IDDM. Diabetes. 45:749-754.

5. Jiang, Z., and Woda, B.A. 1991. Cytokine gene expression in the islets of the diabetic Biobreeding/Worcester rat. J. Immunology. 146:2990-2994.

6. Hirasawa, K., et al. 1997. Possible role of macrophage-derived soluble mediators in the pathogenesis of encephalomyocarditis virus-induced diabetes in mice. J. Virol. 71:4024-4031.

7. Foulis, A.K., Farquharson, M.A., and Meager, A. 1987. Immunoreactive alpha-interferon in insulin-secreting beta cells in type 1 diabetes mellitus. Lancet. 2:1423-1427.

8. Foulis, A.K., McGill, M., and Farquharson, M.A. 1991. Insulitis in type 1 (insulin-dependent) diabetes mellitus in man: macrophages, lymphocytes, and interferon- $\gamma$ containing cells. J. Pathol. 165:97-103.

9. Huang, X., et al. 1995. Interferon expression in the pancreases of patients with type I diabetes. Diabetes. 44:658-664.

10. Hussain, M.J., Peakman, M., and Gallati, H. 1996. Elevated serum levels of macrophage-derived cytokines precede and accompany the onset of IDDM. Diabetologia. 39:60-69.

11. Delaney, C.A., Pavlovic, D., Hoorens, A., Pipeleers, D., and Eizirik, D.L. 1997. Cytokines induce deoxyribonucleic acid strand breaks and apoptosis in human pancreatic islet cells. Endocrinology. 138:2610-2614.

12. Røder, M.E., et al. 1994. Disproportionately elevated proinsulin levels precede the onset of insulin-dependent diabetes mellitus in siblings with low first phase insulin responses. J. Clin. Endocrinol. Metab. 79:1570-1575.

13. Spinas, G.A., Snorgaard, O., Hartling, S.G., Oberholzer, M., and Berger W. 1992. Elevated proinsulin levels related to islet cell antibodies in firstdegree relatives of IDDM patients. Diabetes Care. 15:632-637.

14. Hartling, S.G., Lindgren, F., Dahlqvist, G., Persson, B., and Binder, B. 1989. Elevated proinsulin in healthy siblings of IDDM patients independent of HLA identity. Diabetes. 38:1271-1274.

15. Heaton, D.A., et al. 1988. Increased proinsulin levels as an early indicator of $\beta$-cell dysfunction in non-diabetic twins of type 1 (insulin-dependent) diabetic patients. Diabetologia. 31:182-184.

16. Keymeulen, B., et al. 1998. Implantation of standardized beta-cell grafts in a liver segment of IDDM patients: graft and recipient characteristics in two cases of insulin-independence under maintenance immunosuppression for prior kidney graft. Diabetologia. 41:452-459.

17. Ling, Z., and Pipeleers, D. 1996. Prolonged exposure of human $\beta$ cells to elevated glucose levels results in sustained cellular activation leading to a loss of glucose regulation. J. Clin. Invest. 98:2805-2812.

18. Eizirik, D.L., et al. 1994. Cytokines suppress human islet function irrespective of their effects on nitric oxide generation. J. Clin. Invest. 93:1968-1974.

19. Southern, C., Schulster, D., and Green, I.C. 1990. Inhibition of insulin secretion by interleukin- $1 \beta$ and tumor necrosis factor- $\alpha$ via an L-arginine dependent nitric oxide generating mechanism. FEBS Lett. 276:42-44.

20. Green, L., et al. 1982. Analysis of nitrate, nitrite and $\left({ }^{15} \mathrm{~N}\right)$ nitrate in biological fluids. Anal. Biochem. 126:131-138.

21. Zambre, Y., et al. 1998. Effect of glucose on production and release of proinsulin conversion products by cultured human islets. J. Clin. Endocrinol. Metab. 83:1234-1238.

22. Kiekens, R., et al. 1992. Differences in glucose recognition by individual rat pancreatic $\beta$ cells are associated with intercellular differences in glucose-induced biosynthetic activity. J. Clin. Invest. 89:117-125.

23. Pipeleers, D.G., et al. 1985. Interplay of nutrients and hormones in the regulation of insulin release. Endocrinology. 117:824-833.

24. Bowsher, R.R., Wolny, J.D., and Frank, B.H. 1992. A rapid and sensitive radioimmunoassay for the measurement of proinsulin in human serum. Diabetes. 41:1084-1090.

25. Ling, Z., et al. 1998. Intercellular differences in interleukin $1 \beta$-induced suppression of insulin synthesis and stimulation of non-insulin protein synthesis by rat pancreatic $\beta$ cells. Endocrinology. 139:1540-1545.

26. Köhler, T. 1995. Design of suitable primers and competitor fragments for quantitative PCR. In Quantitation of $m R N A$ by polymerase chain reaction: nonradioactive PCR methods. D. Laßner, A-K. Rost, B. Thamm, B. Pustowoit, and H. Remke, editors. Springer-Verlag. Berlin, Germany. 15-24.

27. Alarcon, C., Leahy, J.L., Schuppin, G.T., and Rhodes, C.J. 1995. Increased secretory demand rather than a defect in the proinsulin conversion mechanism causes hyperproinsulinemia in a glucose-infusion rat model of non-insulin dependent diabetes mellitus. J. Clin. Invest. 95:1032-1039.

28. Gadot, M., Ariav, Y., Cerasi, E., Kaiser, N., and Gross, D.J. 1995. Hyperproinsulinemia in the diabetic Psammomys obesus is a result of increased secretory demand on the $\beta$ cell. Endocrinology. 136:4218-4223.

29. Seaquist, E.Z., et al. 1996. Hyperproinsulinemia is associated with increased $\beta$ cell demand after hemipancreatectomy in humans. J. Clin. Invest. 97:455-460.

30. Rhodes, C.J., and Alarcon, C. 1994. What $\beta$-cell defect could lead to hyperproinsulinemia in NIDDM? Some clues from recent advances made in understanding the proinsulin-processing mechanism. Diabetes. 43:511-517.

31. Gross, D.J., Leibowitz, G., Cerasi, E., and Kaiser, N. 1996. Increased susceptibility of islets from diabetes-prone Psammomys obesus to the deleterious effects of chronic glucose exposure. Endocrinology. 137:5610-5615. 